\title{
Fuzzy Delphi Method (fdm): Determining phase for multicultural-based model of peace education curriculum for preschool children
}

\author{
Noor Amy Afiza Mohd Yusof ${ }^{1}$, Saedah Siraj ${ }^{1}$, Mariani Md Nor ${ }^{1}$, Azli Ariffin"2 \\ ${ }^{1}$ Universiti Malaya, Malaysia, ${ }^{2}$ Sultan Idris Education University, Malaysia
}

Received: 9 March 2018; Accepted: 7 May 2018; Published: 4 June 2018

\begin{abstract}
Recently, peace has become an issue being discussed especially in regards to cultural diversity. With education, peace can be conveyed to all walks of life and levels, in particular, the children as our future generation. This study aimed to determine phases and their interrelation towards multicultural-based model of peace education curriculum for preschool children. In order to acquire the accepted (agreement) value for each phase and their interrelation based on experts' opinion, the Fuzzy Delphi Method was adopted. A set of questionnaire was administered to a group of 12 experts selected based on specified criteria. Seven phases (internal awareness, external stimuli, self- formation, personality cultivation, character development, identity development and action build-up) was given to each expert for their suitable selection of the model. Only 4 phases were selected based on the agreement value of above $75 \%$ while their interrelation was stipulated by defuzzification value of the phases from high to low value. The interrelated and selected phases were internal awareness, personality cultivation, character development and action build-up.
\end{abstract}

Keywords: Peace education, cultural diversity, Fuzzy Delphi Method, preschool children.

\section{Introduction}

Education is a key for uniting nation and bringing people closer to each other. Education should be recognized as important element contributing to the cultivation of peace culture among global communities (Alfonso, 2014). Peace education is a vital component in quality education fundamentals. UNICEF (1999) defines peace education as a process that encourages knowledge, skills, attitude and values needed to alter behavior. This will enable prevention of children, youths as well as adults from structures of conflicts and violence. It will further drives to conflict resolution in peaceful manner, thus creating conducive environment for peace, either in the context of intrapersonal, interpersonal, groups, national as well as international.

\footnotetext{
*Email: azli@fpm.upsi.edu.my
} 
Peace education is increasingly emphasized in particular by peace researchers such as Betty Reardon (1997) and Douglas Roche (1997). Meanwhile, James Page (2008) suggests peace education can be considered promoting commitment for peace as a type of boost for individual confidence as a peace agent. This may come in situations such as telling the students about the consequences of social injustice and war, structural value and thrive to enforce or develop social structure, encourage love in students to the world and imagine a peaceful future, in addition to be concerned of the students and encourage them to be concerned of other people.

Most of the discussions on the role of culture in development are often perceived as an ancient trap, mystical haze, or a source of power hegemony. Such views have not been proven to serve as useful guide for mass actions (Walton \& Rao, 2004). Development thinking has recently arrived at an interesting intersection. In the academic world, economists are struggling with model that works on how social and cultural factors shape human behavior. Academic anthropologists have long been struggling with cultural needs to move beyond criticism towards a more convenient anthropology (Sillitoe, 1998).

Similarly in today's world policy, culture is increasingly seen as a common thing, a convenient fact to shape life likewise economy or politics that contribute to the development process. Nevertheless there are still some confusion arises on how culture is important (Walton \& Rao, 2004).

Malaysia is a nation with full diversity of culture, race, religion and belief. Thus, unity is the crucial element to develop a peace and progressive nation. In Malaysia context, unity has long been implemented as a concept to achieve progressive nation status. The very aspiration of its establishment and independence is based on peace and unity among the races in the effort to develop and advance the nation align with world's progress.

To reach this goal, aspiration values that should be the foundation of Malaysian lifestyle are needed. Even though these values are long inculcated, they still have to be emphasized for the progress of a sturdy future of this nation. These values are based on the culture of excellence, perseverance, modesty, acceptance, loyalty, meritocracy, education and integrity (1Malaysia, 2016). Peace education in school is an important starting point in facing various challenges in future (Usha, 2014). Therefore, providing children with balanced quality from all aspects should be done in securing their future. With respect to this matter, preparing the most suitable curriculum content is very crucial as it is the basis of a curriculum (Zaharah Husin, 2008). Hence, the necessity of this study coincides with the purpose to develop children with peace for the benefits of themselves, community, environment, culture and the country.

Curriculum is the most important element in the education system. It is the lifeblood of an educational system that will shape the next generation (Mariani, 2016). The writer also accords that in order to generate a quality education system; the curriculum should be dynamic and relevant to the current and future needs. In fact, as quoted from Khalifah Umar al Khattab, "educate your children according to their age ...", then it is appropriate to modify and improve the curriculum from time to time. The National Preschool Standard Curriculum (NPSC) is a curriculum used by all preschools in Malaysia and serves as a guide in the teaching and learning process. The first National Preschool Curriculum was implemented in 2003.

The Curriculum Development Division, Ministry of Education Malaysia has clearly stated the goal of preschool education in the updated and piloted Curriculum Standard and Preschool Assessment papers (CSPA) in 2016. Preschool education aims to develop the potential of four to six years old children in a comprehensive and integrated aspect of physical, emotional, spiritual, intellectual and social, through a learning environment that is safe, nourishing and fun, creative and meaningful. The CSPA goal is to enhance skills, instill 
confidence and shape positive self-concepts in children so they will succeed in the existing environment and prepare to address future challenges and responsibilities.

Group ages of 4 to 6 years are formative levels in the development of a child. Thus, the curriculum is formulated to stimulate the child's potential in a comprehensive and integrated manner in the aspect of mind and creativity development, cultivation and values based on religion and morals, strengthening and stability of emotion and physical nourishment in preparation for community life and formal primary education (National Preschool Curriculum, 2010). Nevertheless, education in Malaysia was found to give no emphasis on peace education as it was not stated specifically in the curriculum (Norbaiyah, Farah Haneem \& Juhaidal, 2014).

Unity as discussed begins from social peace (Nor Suhaila, Suzana \& Nur Salimah, 2014; Askandar, 2007). Social peace starts with inner peace of individuals and their most immediate environment (Abdullah, 2010). This peace-related issue needs to be included in each educational curriculum in Malaysia especially in CSPA. Based on CSPA description discussed earlier, it is clear that there is hardly any approach on peace education whether directly or indirectly in the preschool teaching and learning process. This can be seen in all the six spheres created, which none of them emphasizes on peace. However, peace is an essential foundation in an individual to enable the individual to grow well. For example, a child with communication problem will cause him to feel depressed and does not want to associate with other friends for fear of being ridiculed. This is an example of an unsafe situation that could happen to children. Realizing that such problematic situation is often taken lightly that leads to children facing problem to grow properly and safely. This matter in turn will create an unsafe environment for the children causing them to be vengeful individuals and ultimately affect the children and people around them.

Peace should be instilled first in every child before teaching of any lesson. Teaching on peace needs to be applied in every sphere of CSPA especially the humanitarian sphere that involves learning of other cultures in Malaysia.

\section{Purpose of the study}

This study aims to determine phases and their interrelation towards multicultural-based model of peace education curriculum for preschool children based on experts' opinions. There are two research questions that need to be answered to meet this study purposes which are:

1. What are the phases for multicultural-based model of peace education curriculum for preschool children based on experts' opinions?

2. What are the positions of each phase for multicultural-based model of peace education curriculum for preschool children based on experts' opinions

\section{Methodology}

The Delphi Method itself is a method to set a decision involving several rounds of questionnaire to draw views and opinions from experts regarding the topic researched (Azli, 2017; Linstone \& Turoff, 2002). This method is also known as agreement approach or internal opinion agreement (thoughts, intuition and feelings) from a group of experts whom were selected or voted on. Adler dan Ziglio (1996) stated that Delphi Method is a structured process for collecting and extracting knowledge from a group of experts through series of questionnaires with controlled feedback. This view is aligned with Delbecq et al. (1975) which defined Delphi Method as one of the methods in systematically collecting feedbacks on the experts group's judgment and evaluation on particular issue by implementing a type of 
sequential questionnaires with regards of the views and opinions collected from prior questionnaires. The Delphi Method is also known as method of making assumption based on the assessment from experts. Hence, Hill and Fowles (1975) illustrated Delphi Method as reaction or opinion polling implementation procedure, which are possible and probable in future.

The Delphi method was developed in 1953 by the Research and Development Corporation (RAND) (Cornish, 1977). The method was introduced by Olaf Helmer and Norman Dalkey in solving military-related matters (Helmer, 1983). RAND has reported that this technique evolves in various disciplines through journals and articles. Now, this method has also been used in education (Stricland, Moulton, Strickland \& White, 2010; Baggio, 2008), teaching training (Frazer \& Sadera, 2011), management (Schmiedel, Vom Brocke \& Recker, 2013) Tohidi, 2011; Princess and Yusof, 2009), health education (Bobonich \& Cooper, 2012; Rigby, Schofield, Mann \& Benstead, 2012), public administration (Soares \& Amaral, 2011) sports (Lindsey \& Michelle, 2011); (Herrmann, Kirchberger, Stucki \& Cieza, 2010), Byrne, Wake, Blumberg \& Dibley, 2008), career (Lambeth, 2012), tourism (Garrod, 2012; Lee \& \& Saker, 2000), banking (Bradley \& Steward, 2002), international business (MacCarthy \& Atthirawong, 2003), nursing (Keeney, 2010) model designs (Azli Ariffin, 2017; Muhammad Ridhuan 2014), Pandza, Armbruster \& Dreher, 2007). Served as a research technique, this method contains a questionnaire that is conducted in two or more rounds. After each round, the researcher will present the results so that experts can re-evaluate or retain their original answers. Questionnaires were conducted separately and both researchers and experts did not know each other. This method is often considered to provide good interaction within the group (Rowe, Wright \& Bolger, 1991).

Although this method has been widely used in education field especially in future expectations, this method was found to have some shortcomings (Saedah Siraj, 2007) which listed as follows:

1. Reliability of the data depends on the expertise, if the researcher fails to select the real expert means that the findings will lose its reliability

2. Experiments given repeatedly to the sample will cause boredom

3. Small number of experts results to their inability to solve all the rules in the issues studied

4. Less opportunity to obtain feedback from emotional aspect

George Bojadziev and Maria Bojadziev (2007) in their book entitled 'Fuzzy Sets for Bussiness, Finance and Management' states that Delphi's method has a major disadvantage which requires many repeated rounds and the possibility of inaccurate and subjective data is high.

To solve blurring problem in the expert consensus, researchers from around the world have created new methods adapted from this method. Murray, Ppino and Van Gigch (1985) suggested the application of Fuzzy Theory into Delphi method with semantic variables used to solve the problem of ambiguity in the Delphi method. Klir and Folger (1988) suggested mean normalization mode. While Ishikawa, Amagasa, Shiga, Tomizawa, Tatsuta and Meino (1993) used the maximum-minimum method along with cumulative frequency distribution and Fuzzy marking to compose expert opinion to Fuzzy numbers.

Expert prediction interval values are then used to obtain Fuzzy numbers that will form Fuzzy Delphi. Hsu and Chen (1996) suggested the aggregate method of Fuzzy equations. Using this equation function, the equations between experts can be collected and Fuzzy numbers can be built directly to each expert to determine the degree of agreement between them. The consensus coefficients are then used to aggregate the value of Fuzzy number 
evaluation for all experts. If the value of consent among all specialists is too low, then the questionnaire needs to be conducted once again.

Fuzzy Delphi method gives more advantages compared to the Delphi method. Some of the advantages gained are listed below:

1. Save time of questionnaire

2. Save cost

3. Reduce the total number of surveys, raising the rate of questionnaire improvement

4. Experts can fully express their opinion, ensuring perfection and opinion consistency

Take into account the inevitable ambiguity of the study process. This method does not misinterpret the original opinion of the experts and provides an overview of their real reaction. The Fuzzy Delphi Method consists of six steps that need to be followed in order to acquire the required data. The steps are as follows:

1. Step 1: it is considered that expert $\mathrm{K}$ was invited to determine the importance of evaluation criteria against the variables that will be measured using the linguistic variables (Table 1).

Table 1: Seven Scale of Linguistic Variables

\begin{tabular}{|l|c|}
\hline \multicolumn{1}{|c|}{ LINGUISTIC VARIABLES } & FUZZY SCALE \\
\hline Extremely Disagree & $(0.0,0.0,0.1)$ \\
\hline Strongly Disagree & $(0.0,0.1,0.3)$ \\
\hline Disagree & $(0.1,0.3,0.5)$ \\
\hline Partially Agree & $(0.3,0.5,0.7)$ \\
\hline Agree & $(0.5,0.7,0.9)$ \\
\hline Strongly Agree & $(0.7,0.9,1.0)$ \\
\hline Extremely Agree & $(0.9,1.0,1.0)$ \\
\hline
\end{tabular}

2. Step 2: Converting all linguistic variables into triangular Fuzzy number as suggested in Table 3.2, assuming Fuzzy number is the variable for each criterion for expert $\mathrm{K}$ :

$$
\begin{aligned}
& i=1, \ldots, m, \\
& j=1, \ldots, n, \\
& k=1, \ldots, k \text { dan }
\end{aligned}
$$

$$
r i j=\frac{1}{K}\left[ \pm r_{1} i j r_{2} i j \pm r i j\right]
$$

3. Step 3: For each expert, use vertex method to calculate distance between rij (Chen, 2000). Distance between the two numbers Fuzzym $=\left(m_{1}, m_{2}, m_{3}\right)$ and $\mathrm{n}=\left(m_{1}, m_{2}\right.$, $\left.m_{3}\right)$ are calculate using this formula :

$$
d(\tilde{m} \tilde{n})=\sqrt{\frac{1}{3}}\left[\left(m_{1}-n_{1}\right)^{2}+\left(m_{2}-n_{2}\right)^{2}+\left(m_{3}-n_{3}\right)^{2}\right]
$$

4. Step 4: According to Cheng and Lin (2002), if the acceptable value of $d$ is $(d<0.2)$, experts consensus was achieved. Among the experts $m \times n$, if the group's consensus percentage is more than 75\% (Chu \& Hwang, 2008; Murry \& Hammons, 1995) step 
5 can be carried on. Otherwise, round two of Fuzzy Delphi Method (FDM) should be repeated.

5. Step 5: Fuzzy evaluation aggregated with :

$$
\mathrm{i}=1, \ldots, m=\left[\begin{array}{c}
\tilde{\mathrm{A}}_{1} \\
\tilde{\mathrm{A}}_{2} \\
\vdots \\
\tilde{\mathrm{A}} m
\end{array}\right]
$$

6. Step 6: For each alternative, Fuzzy evaluation $A i=A i=\left(a_{1}, a_{2}, a_{3}\right)$ is defuzzificated with formula :

$$
a i=\frac{1}{4}\left(a_{1}+2 a_{2}+a_{3}\right)
$$

Alternative ranking sequence can be determined by $a i$ value.

Experts' agreement value and defuzzification are results that will show analyzed data based on experts' approval given by provided checklist.

\section{Analysis report of FDM}

Fuzzy Delphi Method is applied to observe experts agreement obtained for this study. Based on the collected data, the data was analyzed to acquire threshold value (d). Threshold value should be less than 0.2 to illustrate experts' agreement on the proposed items. Should the value be more than 0.2, it means that there are respondent disagrees with the group on particular item (Azli, 2017; Cheng \& Lin, 2002). According to Chu and Hwang (2008) as well as Murry and Hammons (1995) in Azli (2017), agreement of experts group must be above $75.0 \%$ to meet the criteria used to evaluate group's agreement. Should the result be lower than $75.0 \%$, evaluation should be repeat until the agreement is reached. After the value percentage $\mathrm{d}$ exceeds $75.0 \%$, data analysis process for FDM is continued by defuzzification value calculation. 


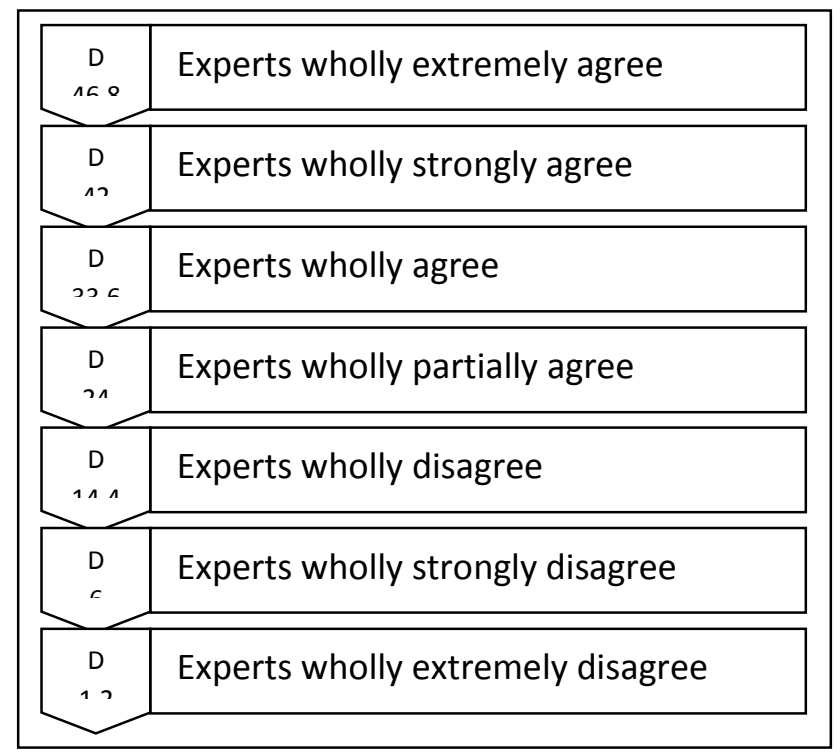

Diagram 1: Experts Agreement Range

Defuzzification value determines experts agreement level towards particular items in the model content of peace education curriculum. Acceptable range of agreement value is between 33.6 to 46.8 (Azli, 2017; Nurulrabihah, 2014). Acceptable minimum value of defuzzification for all items is 24 , while 46.8 as the maximum value. Diagram 1 shows the breakdown for experts agreement range.

\section{Sample of study}

According to Adler and Ziglio (1996), suitable number of experts for Delphi Method is between 10 to 15 persons, while Jones and Twiss (1978) suggest 10 to 50 experts. Expert selection is based on the following criteria:

1. All experts have 10 years as the minimum experience on their respective field.

2. Experts should be possess knowledge on the model that has been built

3. Experts should be willing and interested in this study

4. Experts should be able to provide feedback on the curriculum content model that has been developed

This study once again conducts the sample selection using purposive sampling method. According to Etikan, Musa and Alkassim (2016), there are various types of purposeful sampling. For this phase, type of expert sample is selected. The sampling through this type of expert sample involves experts in the related field of study purposes. The use of this sample type is particularly relevant when it involves the exploration of a new era in the study as well as to collect needs assessment for further research. This study involved 12 experts consisting 3 curriculum experts, 2 state education experts, 2 multicultural experts, 2 early childhood education experts and 3 preschool teachers. 


\section{Research instrument}

Instrument used in this study is a set of 7 scales questionnaires. The questionnaires were divided into two sections namely demographic and phase list. All the items were constructed to answer the research questions. Pilot research is conducted first to see how far the items specified in the completed questionnaire are valid and usable. Face validity is done by selecting three experts to determine clarity of the item, questions posed, adequate response time and item's ability to measure what should be measured. Reliability of the questionnaire was measured through Cronbach Alpha value. This value is obtained using data analyzed through SPSS. High validity and trust are needed to enable actual research to be carried out. If otherwise, items with low validity and reliability values need to be corrected until they reach the value of Cronbach Alpha 0.6 and above.

Table 2. Value of Cronbach Alpha pilot study needs analysis

\begin{tabular}{cc}
\hline ALFA CRONBACH & NO OF ITEM (N) \\
\hline 0.918 & 12 \\
\hline
\end{tabular}

Based on table 2, the Cronbach Alpha value obtained for the need analysis is 0.918 for the entire 12 items. This value is within the range of 0.8 and above, which is within the range of high reliability and reliability values. Therefore, the items in the constructed questionnaire can be used for real research without any need for improvement.

\section{Research analysis}

Table 3 shows percentage value of experts' agreement and accepted defuzzification value from seven phases proposed in the questionnaires. The accepted value will determine whether all phases are completely accepted, rejected or partially accepted. Besides, determination of priority and position of each phase is defined by the accepted value. Based on the table below, there are four phases which acquired acceptable percentage value of experts agreement which is above $75 \%$. The phases are internal awareness (90\%), personality cultivation (85\%), character development (87\%) and action buildup (88\%). This shows that only four phases are suitable to be applied in Multicultural-Based Model of Peace Education Curriculum for Preschool Children and it answers the first research question.

Table 3. Defuzzification percentage and values of phases

\begin{tabular}{|l|c|c|}
\hline \multicolumn{1}{|c|}{ Phase } & Percentage (\%) & $\begin{array}{c}\text { Defuzzification } \\
\text { Value }\end{array}$ \\
\hline Internal Awareness & 90.0 & 44.0 \\
\hline External Stimuli & 65.0 & 22.3 \\
\hline Self Formation & 70.0 & 21.3 \\
\hline Personality Cultivation & 85.0 & 42.2 \\
\hline Character Development & 87.0 & 40.5 \\
\hline Identity Development & 68.0 & 20.6 \\
\hline Action Buildup & 88.0 & 40.2 \\
\hline
\end{tabular}


To answer the second research queaition,accepted defuzzificaiton value will determine the positions in sequence of the consturcted model. Based on the table above, the phases are position in sequence as follows; internal awareness (44.0), personality cultivation (42.2), character development (40.5) and action buildup (40.2). The produced model is divided into four phases which are internal awareness phase, personality cultivation phase, character development phase and action buildup phase. Internal awareness phase contains element that should be instilled in the children at their early stage to create awareness on peace. Without this awareness, they are unable to foresee its importance upon themselves and their future.

The second phase being proposed is personality cultivation. Personality signifies attitude values of an individual. Therefore, this phase is about cultivating peace attitude within the children after going on internal awareness phase. It is important to ensure the children with internal awareness translate it to peace awareness by their attitudes and actions.

The third phase proposed is character development. Character is defined as habits or norms. Selection of this phase is due to acquisition of internal awareness and cultivated peace attitude in the children. Thus, it is important for them to consistently practicing the peace attitude values no matter where they are and what situation they are in.

The last phase proposed by experts is action buildup phase. Due to the fact that character is a system of confidents and habits that directs the action of an individual, so this phase is created. This phase shows whether the children has master the peace concept or otherwise. Should the children failed to realize the elements within this phase, this means that the children has still yet to understand and mastering the peace concept.

For models that have been developed, implementation should begin with the first phase which is internal awareness phase. The second, third and fourth phases can only take place after the first phase is completed. Similarly, the second phase can only be done after the first phase is successful. The third phase should not be carried out if the first and second phases are not completed. While the last phase can only be done after the three phases are successful. The model implementation must be in accordance with phase sequence and assisted by the direction of arrow as shown in the constructed model.

\section{Conclusion}

The creation of a complete model requires a detailed description. This is to ensure easier understanding on the implementation of the model. This model is divided into four phases which are internal awareness phase, personality cultivation phase, character development phase and action build-up phase. These phases were created based on experts agreement value involved in the FDM process. The relation of a phase with another then shows their interrelatedness. Based on UNESCO's statement on peace in 2005, it clearly shows the relation of a phase with another. For the constructed model, implementation should start with the first phase which is internal awareness phase. The second, third and fourth phase could not be continued if the first phase is not conducted. Same goes to second phase which can only be carry on if first phase has been done. Third phase cannot be done until the first and second phase has not been done. Lastly, the fourth phase can only be done after all three phases has been done successfully. As a conclusion, phase and their interrelation in construction of Multicultural-Based Model of Peace Education Curriculum for Preschool Children could assist in a more organized and convenient model implementation process. An organized implementation enables the teachers to conduct evaluation on the children achievement level of this model. 


\section{References}

1 Malaysia (2016). Retrieved at http://www.1malaysia.com.my/

Abdullah, A. (2010). Tema dan isu penyelidikan mengenai gejala sosial pada dekad pertama abad 21 di Malaysia. Akademika, 78, 3-14.

Adler, M. \& Ziglio, E. (1996). Gazing into the oracle. Jessica Kingsley Publishers: Bristol, PA.

Alfonso, S. M. (2014). Peace Education in Early Childhood. Journal of Peace Education and Social Justice, 8(2), 167-188.

Askandar, K. (2007). Perpaduan dan Perdamaian Etnik.

Azli Ariffin (2017). Reka Bentuk Model Aktiviti Penggunaan Lagu Kanak-Kanak Melayu Tradisional Untuk Peningkatan Imaginasi-Kreatif Prasekolah (Doctoral dissertation, University of Malaya).

Baggio, B. G. (2008). Integrating social software into blended-learning courses: A Delphi study of instructional-design processes. proQuest.

Bobonich, M., \& Cooper, K. D. (2012). A core curriculum for dermatology nurse practitioners: Using Delphi technique. Journal of the Dermatology Nurses' Association, 4(2), 108.

Bradley, L. \& Stewart, K. (2003). A Delphi study of interest banking. Marketing Intelligence \& Planning, 21(5), 272-281.

Byrne, S., Wake, M., Blumberg, D., \& Dibley, M. (2008). Identifying priority areas for longitudinal research in childhood obesity: Delphi technique survey. Int $J$ Pediatr Obes, 3, 120-212.

Bojadziev, G \& Bojadziev, M. (2007). Fuzzy Logic for Business, Finance, and Management ( $2^{\text {nd }}$ eds.). Canada: World Scientific.

Chen, C. (2000). Extensions of the TOPSIS for group decision making under fuzzy environment. Fuzzy Sets and Systems 114, 1-9.

Cheng, C. H. \& Lin, Y. (2002). Evaluating the best main battle tank using fuzzy decision theory with linguistic criteria evaluation. European Journal of Operational Research 142:174, 86.

Chu, H. \& Hwang, G. (2008). A Delphi-based approach to developing expert systems with the cooperation of multiple experts. Experts Systems with Applications 34:28, 26-40.

Cornish, E. (1977). The study of the future. World Future Society: Washington, D.C.

Delbecq, A. L., Van de Ven, A. H. \& Gustafson, D. H. (1975). Group techniques for program planning: a guide to nominal group and Delphi process. Glenview, IL: Scott, Foresman and Company.

Etikan, I., Musa, S. A., \& Alkassim, R. S. (2016). Comparison of convenience sampling and purposive sampling. American Journal of Theoretical and Applied Statistics, 5(1), 14.

Frazier, L. \& Sadera, W. (2011, March). Distance education in teacher education: a national study. Society for Information Technology \& Teacher Education International Conference, 1, 280-287.

Garrord, B. (2012). Applying the Delphi method in an ecotourism context: a response to Deng et al.'s 'Development of a point evaluation system for ecotourism destinations: a Delphi method'. Journal of Ecotourism, 11(3), 219-223.

Helmer, O. (1983). Looking forward: a guide to future research. Beverly Hills, CA: Sage.

Herrmann, K. H., Kirchberger, I., Stucki, G. \& Cieza, A. (2010). The comprehensive ICF core sets for spinal cord injury from the perspective of physical therapist: a worldwide validation study using the Delphi technique. Spinal Cord. doi:10.1038/sc.2010.155. Retrieved from http://www.nature.com/sc/journal/vaop/ncurrent/full/sc2010155a.html 
Hill, K.Q. \& Fowles, J. (1975). The methodological worth of the Delphi forecasting technique. Technology and Forecasting and Social Change, 7, 179-192.

Hsu, H. M. \& Chen, C. T. (1996). Aggregation of fuzzy opinions under group decision making. Fuzzy Sets and Systems, 79, 279-285.

Ishikawa, A., Amagasa, M., Shiga, T., Tomizawa, G., Tatsuta, R. \& Mieno, H. (1993). The max-min delphi method and fuzzy Delphi method via fuzzy integration. Fuzzy Sets and Systems, 55(3), 241-253.

Jones, H., \& Twiss, B. C. (1978). Forecasting technology for planning decisions (No. 658.4 J6).

Jung-Erceg, P., Pandza, K., Armbruster, H. \& Dreher, C. (2007). Absorptive capacity in European manufacturing: a Delphi study. Industrial Management \& Data Systems, 107(1), 37-51.

Keeney, S. (2010). The Delphi Technique. In: The research process in nursing. UK: WileyBlackwell.

Kementerian Pelajaran Malaysia (2003). Kurikulum Prasekolah Kebangsaan. Pusat Perkembangan Kurikulum.

Kementerian Pelajaran Malaysia (2010). Kurikulum Standard Prasekolah Kebangsaan. Bahagian Pembangunan Kurikulum.

Kementerian Pelajaran Malaysia (2011). Kurikulum Standard Prasekolah Kebangsaan. Pusat Perkembangan Kurikulum.

Kementerian Pelajaran Malaysia (2016). Dokumen Standard Kurikulum dan Pentaksiran. Pusat Perkembangan Kurikulum.

Klir, G. J. \& Folger, T. A. (1988). Fuzzy sets, uncertainty, and information. Prentice-Hall International.

Lambeth, J. M. (2012). Research foci for career and technical education: findings from a national Delphi study (Doctoral dissertation). Retrieved from https://repositories.tdl.org/tdl-ir/handle/1969.1/ETD-TAMU-2864

Lee, C. F. \& King, B. (2009). A determination of destination competitiveness of Taiwan's hot springs tourism sector using the Delphi technique. Journal of Vacation Marketing, 15(3), 243-257.

Lindsey, E. Eberman \& Michelle, A. Cleary (2011). Development of a heat-illness Screening Instrument Using the Delphi Panel Technique. Journal of Athletic Training, 46(2), 176-184.

Linstone, H. A., \& Turoff, M. (2002). The Delphi method: Techniques and applications (Vol. 18). Addison-Wesley Publishing Company, Advanced Book Program.

MacCarthy, B. L. \& Atthirawong, W. (2003). Factors affecting location decisions in international operations-a Delphi study. International Journal of Operations \& Production Management, 23(7), 794-818.

Mariani Md Nor (2016). Transformasi Dasar dan Kualiti Pendidikan Prasekolah. Dalam Hussein Haji Ahmad \& Mohammed Sani Ibrahim (2016). Transformasi Pendidikan Nasional: Antara Aspirasi dan Anjakan. Kuala Lumpur: Penerbit Universiti Malaya. Muhammad Ridhuan Tony Lim Abdullah (2014). PhD Dissertation.

Muhammad Ridhuan Tony Lim Abdullah, Saedah Siraj, Asra \& Zaharah Hussin (2014). Interpretive Structural Modeling of Mlearning Curriculum Implementation Model of English Language Communication Skills for Undergraduates. The Turkish Online Journal of Educational Technology, 13(1).

Murray, T., Pipino, L., \& Van Gigch, J. (1985). A pilot study of fuzzy set modification of Delphi. Human Systems Management Vol 5, 76-80.

Murry, J. \& Hammons, J. (1995). Delphi: a versatile methodology for conducting qualitative research. Review of Higher Education 18:4, 23-36. 
Nor Suhaila, C. P., Suzana, S., \& Nur Salimah, A. (2014). Tahap perpaduan pelajar pelbagai etnik melalui penggunaan teknologi dalam aktiviti pembelajaran.

Norbaiyah Abd Kadir, Farah Haneem Ahmad Jamal \& Juhaida Ismail (2014). Peace Education: Inculcating Global Peace Values among Students through Literary Texts in Malaysia. Proceeding of the Global Summit on Education GSE 2014. Kuala Lumpur, Malaysia.

Nurulrabihah Mat Noh (2014). Reka bentuk kerangka piawai Facebook sebagai medium pengajaran dan pembelajaran sekolah menengah. Unpublished doctoral dissertation. Universiti Malaya.

Page, J. S. (2008). Philosophy of Peace Education. In B., Monisha (ed.) Online Encyclopedia of Peace Education. New York: Columbia University, Teachers College.

Putri, N. T. \& Yusof, S. R. M. (2009). Development tool for prioritizing and measuring the critical success factors of quality engineering implementation (Case study at Malaysian and Indonesian Automotive Industries). In Proceeding of Asia Pasific Industrial Engineering and Management Systems conference.

Reardon, B. A. (1997). Human rights as education for peace. In G. J. Andrepoulos and R. P. Claude (Eds.), Human rights education for the twenty-first century (pp. 255-261). Philadelphia, PA: University of Pennsylvania Press.

Rigby, H., Schofield, S., Mann, K. \& Benstead, T. (2012). Education research: An exploration of case-based learning in neuroscience grand rounds using the Delphi technique. Neurology, 79(3), e19-e26.

Roche, D. (1997). "Expanding Human Loyalties." In Joseph Rotblat, Editor. 1997. World Citizenship: Allegiance to Humanity. St. Martin's Press, New York. 134-144.

Rowe, G., Wright, G., \& Bolger, F. (1991). Delphi a reevaluation of research and theory. Technological Forecasting and Social change, 35-51.

Schmiedel, T., Vom BRocke, J. \& Recker, J. (2013). Which cultural values matter to business process management? Results from a global Delphi study. Business Process Management Journal, 19(2), 5-5.

Saedah Siraj (2007). Future state curriculum planning. Keynote Address \& Poerpoint Presentation at International Seminar on Future State Curriculum Planning: prospect and Challenges. Pangkep Province, South of Sulawesi, Indonesia.

Sillitoe, P. (1998). The development of indigenous knowledge: A new applied anthropology. Current anthropology, 39(2), 223-252.

Soares, D. \& Amaral, L. (2011). Information systems interoperability in public administration: identifying the major acting forces through a Delphi study. Journal of theoretical and applied electronic commerce research, 6(1), 61-94.

Story, V., Hurdley, L., Smith, G. \& Saker, J. (2000). Methodological and practical implications of the Delphi technique in marketing decision-making: A reassessment. The Marketing Review, 1(4), 487-504.

Strickland, J., Moulton, S., Strickland, A. \& White, J. (2010). The Delphi technique as an evaluation tool: An example of developing an e-learning curriculum using the ADDIE model. In J. Sanchez \& K. Zhang (Eds.), Proceedings of World Conference on E-Learning in Corporate, Government, Healthcare and Higher Education 2010 (pp. 2203-2211). Chesapeake, VA: AACE.

Tohidi, H. (2011). Review the benefits of using value engineering in information technology project management. Procedia Computer Science, 3, 917-924.

UNESCO (2005). UN Decade of Education for Sustainable Development 2005 - 2014: The DESD at a glance. Paris: UNESCO

UNICEF (1999). Progress, Challenges and Future Strategies in Basic Education. E/ICEF/1999/14 (Paper tabled at June 1999 Executive Board Session). 
UNICEF (1999). The Future Global Agenda for Children: Imperatives for Twenty-First Century. E/ICEF/1999/10 (Executive Board Document).

Usha, A. B. (2014). Transacting Peace Education in School Using PETS: A Study. IOSR Journal of Research and Method in Education, 4(1), 30-34.

Walton, M., \& Rao, V. (2004). Culture and public action. Stanford University Press.

Zaharah Hussin. (2008). Pembinaan Kandungan Kurikulum Pendidikan Akhlak Latihan Perguruan Pendidikan Islam di Malaysia. Unpublished Ph.D. Thesis, Education Faculty, Universiti Malaysia. 